\title{
Reconsidering the Implementation of Participatory Action Research and Community Development Courses at Sociology Department
}

\author{
Sulistyaningsih* \\ Sociology Department \\ Faculty of Social Sciences and Humanities, \\ UIN Sunan Kalijaga \\ Yogyakarta, Indonesia \\ sulistyaningsih@uin-suka.ac.id
}

\begin{abstract}
This paper aims to explore how the implementation of Participatory Action Research (PAR) and Community Development subjects in 2019 at Sociology Department, UIN Sunan Kalijaga. This research uses qualitative approach. The data were collected from interview, documents, and focused group discussion. Data analysis method was done through data reduction, data display and conclusion. The results of the study show that the implementation of Participatory Action Research and Community Development Subjects has not been carried out optimally. There are still necessary efforts that need to be improved, such as: first, the Semester Learning Plan of the two subjects must be adjusted to the Indonesian National Work Competency Standards (SKKNI) based on the Decree of the Minister of Manpower of the Republic of Indonesia No. 81/2012. Second, there is a need for monitoring and evaluation in the practice of this subject more intensively. Third, there is a need to follow up actions continuously.
\end{abstract}

Keywords-Community, development, theory, participatory, and practice.

\section{INTRODUCTION}

The vision of Sociology Department, Faculty of Social Sciences and Humanities, UIN Sunan Kalijaga is "becoming prominent in integrating and developing sociology and Islamic studies to produce sociologist with Islamic insights". Meanwhile, the department's missions are: to develop the education and teaching of Islamic sciences and social sciences in an integrated manner; to develop studies and research in the field of social sciences, especially related to socio-religious phenomena; and develop cooperation with other institutions, both domestic and overseas [1].

Sociology Department has three objectives: first, establishing Sociology Study Program as a center for the development of Islamic-oriented Sociology studies; second, producing scholars who master a variety of Sociological perspectives and are able to apply them in the research and development of Islamic-oriented sociology of science; and three, producing undergraduate sociology who are able to apply the field of science of Sociology for community empowerment by paying attention to Islamic values and nationality. The main profiles of graduates of Sociology Department are to become academics (Analysts / Researchers / Educators) in Sociology as well as practitioners (Community Organizer / Social Consultants / NGO Activists).

One effort to realize these three objectives from Sociology Department was designing curriculum that fit the needs of society. The curriculum is manifested through various subjects in Sociology Department. Supporting subjects for graduate competencies to become practitioners are Participatory Action Research (PAR) and Community Development. Participatory Action Research (PAR) subject is taken by students in the fifth semester, while Community Development subject is taken during the sixth semester. Both subjects have been held since 2013 until now. In the 2013 curriculum, the name of the Community Development course was Community Assistance and was carried out in the seventh semester. Due to a change in 2016 curriculum, the name of the Community Assistance subjects was changed to Community Development and it was held in the sixth semester. The purpose of this paper is to explore how the implementation of the practices of both PAR and Community Development subjects in 2019?

\section{THEORETICAL PERSPECTIVE AND RESEARCH METHOD}

The Theoretical Perspective

Community Development is one method of social work whose main purpose is to improve the quality life of the community through the utilization of all resources available to them and emphasizes on the principle of social participation. In general, Community Development includes planning, coordinating and developing various community programs or projects. As a collective activity, community development involves several actors, such as social workers, local communities, donor agencies and other related agencies, who collaborate each other, starting from creating certain designs, their implementations, to making an evaluation of the programs or projects [2].

Community development According to Twelvetrees in [2] is the process of assisting ordinary people to improve 
their own communities by undertaking collective action. Community Development is an effort that seeks to fulfill the needs of people who are not fortunate because of the factors of poverty or because of discrimination of various aspects such as social class, ethnicity, gender, gender, age, and disability.

Community development has two concepts namely development and society. The development is an effort to improve the quality of human efficacy. Community in this regard is a common place and mutual interest [2].

Twelvetrees divides the theoretical perspective of community development into two domains, namely professional approach and radical approach. Professional approach is interpreted as an effort to enhance the modernists and improve the system of providing services in the framework of social relations. Radical approach is based on the roots of Marxist structural theory, feminism and antiracist analysis. This approach aims to improve the initiative and independence of the community and improve the provision of social services in the framework of existing social relations. [2].

The development of local communities is a process that aims to create social progress in the Economic Community for the people of active participation and initiative community members. Community in this context is as unique as the community and has potential but the potential has not been fully developed optimally. Community development is actually more oriented towards the process objectives. So the community is responsible for determining objectives and choosing the right strategy to achieve that goal. The core of local community development processes based on the paradigm bottom up is the development of local leadership, increased self-reliance strategies, communication, relationships and community involvement [2].

There were various perspectives in community development namely the ecological, social justice and human rights, ecology and social justice and human rights perspectives. The ecological perspective sees environmental problems as social, economic and political problems. Community development must pay attention to the values of social justice and human rights. The ecological perspective and social justice / human rights form the basis of a vision for a future society, which provides a vision of what is socially desirable: a society based on the definition and guarantee of rights, equality, empowerment, which defeat structural oppression and adverse conditions, freedom to determine needs and fulfill those needs [3].

An ideological and theoretical foundation for changes in community development can be obtained through a bottom up approach. In the bottom up practice, there are some important aspects to do, which include: Respect local knowledge, local culture, local resources, local skills, local processes, work and solidarity. Community development must always strive to maximize participation with the aim of making everyone in the community actively involved in community processes and activities and creating the future of society and individuals. Participation is an important part for raising community empowerment and awareness. The more people who are actively involved, the more ideal the ownership and community processes will be realized [3].
Some efforts to encourage community participation in certain programs are: first, people will participate if they feel that the issue or activity is important; second, people feel that their actions will make a change; third, various forms of participation must be recognized and valued; fourth, people must be able to participate and be supported in their participation; and fifth, structure and processes should not exclude.

There are many conducive factors to support participation of community members, such as: full community control, good knowledge and clear understanding of the complexity of participation, clarity of criteria, honesty and openness, access to relevant information, legislation, training local communities in lobbying and advocacy, providing facilitators, strong community network [3]

\section{The Research Method}

This study uses qualitative method. Data obtained by conducting Participatory Action Research. There are three special features of participatory research compare to conventional research, such as: ownership/joint responsibility for the research project, community-based analysis of social issues, orientation to community action. The commitment of Participatory Action Research is focus on the development of socio-political economy as responses to the various needs and opinions of society [4]. Primary data derived from in-depth interview and focused group discussion. While the secondary data using the document (the report of the students taking PAR and Community Development subjects). In-depth interviews were conducted with approximately to 21 students (the leader in group) and focused group discussion was held toward 21 groups (10 groups in Mei 2019 and 11 groups in November 2019). Data analysis method is done through data reduction, data display and conclusion.

\section{RESULT AND DISCUSSION}

\section{Overview of Participatory Action Research and Community Development Subjects}

The study of PAR and Community Development subjects is conducted in accordance with the Semester Learning Plan that has been prepared by supporting letters, signed by the Chair of Sociology Department and the Dean of the Faculty of Social Sciences and Humanities, State Islamic University of Sunan Kalijaga. These PAR and Community Development courses are designed based on theoretical and practical levels. Theory is carried out during 7 class meetings. 7 other meetings after it are practice the theory in the field [5].

Description of PAR course based on syllabi and Semester Learning Plan as follows: This course aims to provide understanding to students about the emergence of PAR Research Methods, studies in PAR, Practices in PAR and provide space for students to practice in this learning process. Learning outcomes imposed on this course are: 1) Understanding the emergence of PAR. 2) Understanding studies in PAR. 3) Ability to map the problems that exist in PAR studies in the community. 4) Ability to provide solutions to problems that exist in society systematically and methodologically. 5) Ability to work in a team. 6) Ability to take responsibility for the achievement of group and 
supervising and evaluating the completion of work assigned to workers under their responsibility. 7) Ability to carry out a process of self-evaluation of work groups under its responsibility and be able to manage learning independently. 8) Ability to take initiative and be innovative [6].

Description of the Community Development subject based on syllabi and Semester Learning Plan as follows: This course is a compulsory subject in Sociology Department. This course aims to provide an overview of community development from the standpoint of Sociology. There are a number of materials that will be raised in this course such as the foundation of Community Development, the idiological and theoretical foundation for change from below, realizing participation in community development, Community Development Process, Application of Principles in Community Development practices. Learning outcomes imposed on this course: 1.) Understanding the theory and techniques of community development. 2) Able to facilitate / assist the community in solving problems. 3.) Providing recommendations for Sociological studies to relevant stakeholders. 4) Able to move the community to become more empowered (community development). 5) Able to work together in carrying out tasks as a scientist and practitioner of Sociology with relevant parties [7].

\section{Overview of Indonesian National Work Competency Standards}

Professional development of Community Empowerment Facilitators along with a quality assurance system for their performance really needs to be done. This will have an impact on the community, user institutions and the community empowerment facilitators. One of the requirements for the formation of a profession for Community Empowerment Facilitators is based on the Indonesian National Work Competency Standards (SKKNI) for Community Empowerment Facilitators [8]. The competencies that exist for community empowerment facilitators in the Indonesian National Work Competency Standards based on the Decree of the Minister of Manpower of the Republic of Indonesia No. 81 of 2012 are Building Social Relations, Optimizing the Utilization of Resources in the Community, Developing Community Awareness to Change Towards a Better Life, Developing Capacity as a Facilitator, Enhancing Accessibility among Stakeholders, Building Community Vision and Leadership, Building Networks and Partnerships, Building Social Solidarity, Developing Institutional Capacity of Local Communities and Local Government, Strengthening Community Negotiating Positions, Designing Changes in Community Lives, Managing Learning in the Community, Preparing for Community Learning Community Empowerment Cadres, Developing Community Independence, Managing Conflict Within Communities, Developing Social Control Systems, Developing Community Empowerment Innovations, Facilitating Implementation of Community Empowerment Innovations in Specific Areas / Sectors of Activities.

\section{Implementation of Participatory Action Research and Community Development Subjects}

The practice scheme of PAR and Community Development courses is carried out by a mechanism of group division. One group consists of 5-6 students. The research theme and location of the practice is given to students to determine in accordance with their interests. The practice of PAR and Community Development courses in the Sociology Study Program has been carried out in 2019. The details of the implementation are as follows:

The theme of PAR practise is about Capacity Building for local organizations. The location for practice is in Bantul District, Sleman District and Yogyakarta City. The activities for practicing PAR are varied, such as: community empowerment through the preservation of education tourism in Jetisharjo, Yogyakarta, Optimizing public reading for Community in Nologaten village, Sleman, Efforts to increase entrepreneurial capacity for students at Borading School of ISC Aswaja Lintang Songo, Piyungan, Bantul, Strengthening the product marketing capacity for Mina Makmur in Sleman Regency, Community empowerment through training in Ngablak village, Piyungan, Bantul, Optimizing Internet use for students at Manakara dormitory Yogyakarta, Capacity building for vegetable aisle Group in Kotagede Yogyakarta, Community empowerment through environmental conservation Program in Tegalrejo, Yogyakarta, Flood disaster mitigation training for elementary school students of Muhammadiyah Karangploso, Sitimulyo, Piyungan, Bantul, Efforts to increase students boarding school ISC Aswaja Lintang Songo, Piyungan, Bantul, Community empowerment through the management of Herbal plants in the hamlet of Babadan, Sitimulyo, Piyungan, Bantul [9].

The Theme of community Development practice is Strengthening Community through local Organization. The location for practice is in Bantul District, Sleman District, Gunungkidul District and Yogyakarta City. The activity for practice such as: Capacity Building in diffable community, Yogyakarta, Community participation in post-flood recovery in Paderesan Hamlet, Imogiri, Bantul, Utilization of social Media as the development of batik sales in Kampung Batk Giriloyo Bantul, Urban Farming-based River Love movement in Jetisharjo, Yogyakarta, The movement fosters a healthy lifestyle in the people of Triharjo, Sleman, Capacity Building for Karang Taruna in Sekartaji Karanggayam village, Bantul, Waste management in Wedomartani village, Sleman Regency, Capacity Building for assisted Children in Yogyakarta Children'S Special Development Board (LPKA), Yogyakarta, Capacity Building for Karang Taruna in Triharjo village, Bantul, The participation of young people in strengthening the literacy of Nologaten village community, Sleman [10].

Substantially the paths undertaken by students in the practice of the two subjects are as follows: observation, assessment through Focused Group Discussion, making proposals, formulating an agenda with the community, carrying out joint activities, monitoring and evaluation and making reports. In practice both subjects use qualitative research methods with Participatory Action Research (PAR). Students conducted practices ranging from 7 to 20 times in the field. These variations are due to the dynamics of each group of students that are not the same. However, in substance, what has been done by the students in practice has at least tried to provide critical awareness for the community to make changes through collective actions in society [11]. The students tried to practice how to learn 
together with the community from the process of planning, implementing activities and evaluating and monitoring [1].

The students also carry out practical activities by considering various perspectives on ecological, social justice and human rights as well as ecological, social justice and human rights perspectives. In addition, students tried to implement change in the community based on bottom up. In this context it means that they pay attention to local aspects related to society such as knowledge, culture, skills and solidarity processes.

Students in practice also try to encourage community participation. In this case there is a group of students who can optimally encourage community participation in the shared learning process. But there are also groups of students who have not been maximal in encouraging community participation [11]. This happens for example when students hold activities, it turns out that support from the community is not optimal. This was because one of them was not yet a belief in the community that what was done by the student group becomes an important issue for the community. In addition, it is also due to internal factors that exist in students such as skills in practice, student network with other partners as well as the ability to advocate and lobby. Participation in this context becomes an important part of community development and awareness raising. The more people who are actively involved, the more ideal the ownership and community processes will be realized $[9,10]$.

The obstacles that occur to these students are also caused by several things such as: First, the time is very limited from both courses. Second, students take both subjects together with other subjects which also require practice. Third, the limitation of roleplay material in class. Fourth, the teaching material delivered in the two subjects has not yet been detailed, referring to the Indonesian National Work Competency Standards based on the Decree of the Minister of Manpower of the Republic of Indonesia Number 81 of 2012 Concerning the Designation of Community Service Sector Sectors for Community Empowerment for the Position of Community Empowerment Facilitators. Fifth, monitoring and evaluation as well as follow-up of the implementation of the practice of the two subjects is not optimal yet.

\section{CONCLUSION}

Based on what was stated above it can be concluded that Based on the results of the study it can be concluded that the implementation of Participatory Action Research and Community Development Practice subjects in Sociology Department has been carried out not optimal. However, there are still things that need to be improved in a number of ways such as: First, the Semester Learning Plan of the two courses must be adjusted with the Community Empowerment Facilitator Certification based on the Indonesian National Work Competency Standards (SKKNI) based on the Decree of the Minister of Manpower of the Republic of Indonesia No. 81 of 2012 Concerning Determination of the Draft Standards for Indonesian
National Work Competency Sector Community Services Sector in the Field of Community Empowerment for the Position of Community Empowerment Facilitator . Second, there needs to be more intense monitoring and evaluation in the practice of this course. Third, there needs to be follow up continuously.

\section{ACKNOWLEDGMENT}

This research is supported by students at Sociology Department taken Participatory Action Research and Community Development subjects in 2019. Thank you so much for the support from Students, The Head of Sociology Department, The Lecturers at Sociology Department, Dean of Social and Humanities, State Islamic University and many stakeholders in Bantul Regency, Sleman Regency, Jogja City and Gunungkidul Regency.

\section{REFERENCES}

[1] Tim Fakultas, 2016, Profil Program Studi Sosiologi, Fakultas Ilmu Sosial dan Humaniora UIN Sunan Kalijaga.

[2] Edi Suharto,2005 "Membangun Masyarakat, Memberdayakan rakyat: Kajian Strategis Pembangunan Kesejahteraan Sosial dan Pekerjaan Sosial,Bandung, PT Refika Aditama.

[3] Jim Ife dan Frank Tesoriero, 2008, Alternatif Pengembangan Masyarakat di Era Globalisasi Community Development, Yogyakarta, Pustaka Pelajar

[4] Norman K Denzin, 2009. Handbook of Qualitative Research, Sage Publication.

[5] Kurikulum Program Studi Sosiologi Fakultas Ilmu Sosial dan Humaniora UIN Sunan Kalijaga, 2016.

[6] Sulistyaningsih, 2019. Silabi dan Rencana Pembelajaran Semester PAR.

[7] Sulistyaningsih, 2019. Silabi dan Rencana Pembelajaran Semester Pengembangan Masyarakat.

[8] SKKNI Kementerian Tenaga Kerja RI No 81 Tahun 2012 Tentang Penetapan Rancangan Standar Kompetensi Kerja Nasional Indonesia Sektor Jasa Kemasyarakatan Bidang Pemberdayaan Masyararakat.

[9] Laporan Kegiatan Praktik Mata Kuliah Participatory Action Research Mahasiswa Program Studi Sosiologi (Student Reports), Fakultas Ilmu Sosial dan Humaniora, UIN Sunan Kalijaga, Tahun 2019.

[10] Laporan Kegiatan Praktik Mata Kuliah Pengembangan Masyarakat Mahasiswa Program Studi Sosiologi Fakultas Ilmu Sosial dan Humaniora UIN Sunan Kalijaga Tahun 2019.

[11] Focused Group Discussion, on May dan November 2019. 